\title{
United States Geological Survey National Water-Use Information Program
}

The USGS provides maps, reports, and information to help others meet their needs to manage, develop, and protect America's water, energy, mineral, and land resources. We help find natural resources needed to build tomorrow, and supply scientific understanding needed to help minimize or mitigate the effects of natural hazards and environmental damage caused by human activities. The results of our efforts touch the daily lives of almost every American.

\section{Background}

The United States possesses abundant water resources and has developed and used those resources extensively. The future health and economic welfare of the Nation's population depend on a continuing supply of uncontaminated freshwater. Many existing sources of water are being stressed by withdrawals from groundwater wells and diversions from rivers and reservoirs to meet the needs of homes, cities, farms, and industries. Increasing requirements to leave water in the streams and rivers to meet environmental, human, and recreational needs further complicate the problem. Recent drought in some areas has accentuated the need to balance water demand with supply.

Traditionally, water management in the United States has focused on manipulating the country's supplies of freshwater to meet the needs of users. A number of large dams were built during the early 20th century to increase the supply of freshwater at any given time. The era of building large dams and conveyance systems to meet water demand in the United States is drawing to a close, as shown in figure 1; as we approach the 21st century, the limited water supply and established infrastructure requires that demand be

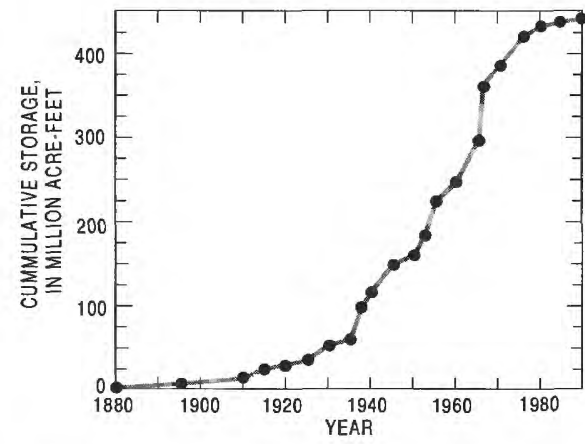

Figure 1. Cumulative reservoir storage in the United States. managed effectively within the available supply.

"New" water supplies likely will be from conservation, recycling, reuse, and improved water-use efficiency rather than from large development projects. It is apparent that the Nation can no longer meet insatiable water demands by continuously expanding a supply that has physical, ecological, and economic limits. The transition is well under way to an era of "integrated water-resources management" in which traditional supply-management options will be balanced with demand-management options.

The Governors of the Western States recently issued a policy statement calling for sharply enhanced efficiency in water use, and the President signed into law the 1994 Energy Policy Bill, which calls for government agencies to take the lead in water-use-efficiency measures and sets new standards for water-conserving plumbing fixtures. Water-resource planners, managers, and hydrologists need comprehensive, credible, and reliable water-use data to assess the impacts and efficiency of demand-management strategies and to balance the competition between traditional uses and new recreational and environmental uses.

\section{National Water-Use Information Program}

The U.S. Geological Survey's (USGS) National Water-Use Information Program is a cooperative program with State and local governments and is designed to collect, store, analyze, and disseminate water-use information nationally and locally to a wide variety of government agencies and private organizations. The program was begun in 1978 to meet the need for a single source of uniform information on water use and to serve as the focal point for water-use information. The Water-Use Program is financed through the Federal-State Cooperative Program of the USGS with Federal-State cooperative matching funds available to support water-use information activities in the 50 States and Puerto Rico. By law, these Federal funds must be matched with equal amounts of State or local agency funds.

\section{Why is the Program in the USGS?}

The USGS has compiled estimates of water use every five years since 1950 . However, before the National Water-Use Information Program was started, these estimates were derived from many sources and were based on a variety of methods of data collection and analysis that differed in accuracy. Therefore, the available information fell short of providing a national data base that was current, readily accessible, and reliable.

Because the USGS has offices in each State, it is in good position to operate and manage the National Water-Use Information Program. The Program compiles data that are used to estimate water use at the State level on the basis of nationally consistent guidelines and procedures, and uniform quality assurance for each State.

\section{Objectives}

The objectives of the National WaterUse Program are to:

- Determine on local and national levels how much fresh and saline ground and surface water is withdrawn and for what purposes

- Develop and refine computerized systems to store and retrieve wateruse information at State and national levels

- Devise and apply new standards, methods, and techniques to improve the collection and analysis of wateruse information 
gated with more than 2 billion gallons of water per day.

\section{Applications of Water-Use Information}

Some examples of specific applications of water-use information are given below.

\section{Kansas}

The USGS, in cooperation with the Kansas State Board of Agriculture's Division of Water Resources, developed a user-support data system incorporating geographic information system technology called the Water Information Management and Analysis System (WIMAS). The system is used to help make decisions about ground-water appropriations and for approval or denial of water-right applications. The WIMAS is used to generate data files for input to a groundwater-flow model and a stream-aquifer model to assess the effect of saline river water on ground-water quality and to investigate the effects of water use on streamflows, respectively.

\section{Georgia}

The USGS, the University of Georgia, and the Georgia Department of Natural

Resources have entered into a joint "benchmark farms" study to establish an irrigation information network in southwestern Georgia. The network will provide State and local officials with more accurate and detailed irrigation data that can be used to manage the water resources and permitting programs more effectively in the State.

\section{Arkansas}

The USGS and the Arkansas Soil and Water Conservation Commission implemented an education and information program that included the preparation of 29 county and 3 area water-use reports. These reports summarize reported sitespecific irrigation and agricultural information in all 75 counties. Computer software developed by the USGS allows Conservation District personnel to remotely enter site-specific irrigation and agricultural water-use data for about 54,000 irrigation and agricultural water users. These data bases provide reliable information for effective management of water resources in Arkansas.

\section{Tennessee}

The USGS provided water-demand modeling in Tennessee to project water demands in the Duck River Basin to determine if the Duck River could supply those demands. The results of this effort are being used by local, State, and Federal decisionmakers to determine if additional impoundments will be needed in the Basin.

\section{Ohio}

The USGS and the Ohio Department of Natural Resources, Division of Water (ODNR-DW), have cooperatively designed and developed the Water Withdrawal Facility Registration Program. This program requires the owners of all facilities in Ohio with the capacity to withdraw 100,000 gallons of water or more per day to register and subsequently to report its withdrawals annually to the ODNR-DW. The data collected as a result of these registrations have and will continue to provide valuable information necessary for the development and management of the State's water resources.

\section{Other Federal Agencies}

The Natural Resource Conservation Service (formerly the Soil Conservation Service) is interested in USGS water-use data bases to aid in making water-demand forecasts for their 1997 Resource Conservation Assessment.

The U.S. Forest Service also is interested in USGS data bases for its 1998 assessment of the future of the Nation's natural resources.

The U.S. Environmental Protection Agency (USEPA) established water-use efficiency as a priority and requires reliable data. The USEPA uses USGS wateruse information to identify the potential effects of hazards of underground storage on the public's drinking water supplies and to identify populations served by ground and surface waters.

—Wayne B. Solley

\section{For more information contact any of the following:}

Office of the Regional Hydrologist, NR

U.S. Geological Survey

433 National Center

Reston, Virginia 22092

(703) 648-5817

Conn., Del., D.C., Ill, Ind., Ky., Maine, Md., Mass., Mich., N.H., N.J., N.Y., Ohio, Pa., R.I.,Vt., Va., W.Va., and Wis.

Office of the Regional Hydrologist, SR U.S. Geological Survey Spalding Woods Office Park

3850 Holcomb Bridge Road, Suite 160

Norcross, Georgia 30092-0223

(404) 409-7701

Ala., Ark., Fla., Ga.,La., Miss., Mo., N.C.,

P.R., S.C., Tenn., and V.I.

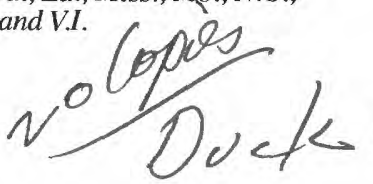

Office of the Regional Hydrologist, CR

U.S. Geological Survey

Mail Stop 406, Box 25046

Denver Federal Center

Lakewood, Colorado 80225

(303) 236-5920

Colo., Iowa, Kans., Minn., Mont., Nebr., N. Mex., N. Dak., Okla., S. Dak., Tex., and Wyo.

Office of the Regional Hydrologist, WR

U.S. Geological Survey

345 Middlefield Road, Mail Stop 470

Menlo Park, California 94025-3591

(415) 329-4414

Alaska, Ariz., Calif., Guam, Hawaii, Idaho, Nev., Oreg., Utah, and Wash.
Chief, Branch of Water-Use Information U.S. Geological Survey 414 National Center

Reston, Virginia 22092 (703) $648-5226$

Additional earth science information can be found by accessing the USGS "Home Page" on the World Wide Web at "http://www.usgs.gov", or by calling 1-800-H20-9000 (1-800-426-9000)

For more information on all USGS reports and products (including maps, images, and computerized data), call 1-800-USA-MAPS.

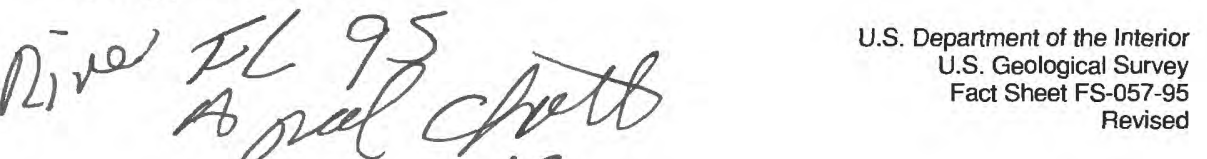


- Disseminate water-use information at State and national levels

\section{Accomplishments}

Through the cooperative water-use program, standardized collection and analysis methods are developed that allow evaluations on the basis of similar assumptions and comparable data, site specific water-use data bases are being developed to help ensure effective, efficient communication and data handling among other Federal agencies, the States, and the USGS, and the data are aggregated at 5-year intervals and published in the USGS circular series Estimated Use of Water in the United States to respond to interstate, regional, and national wateruse data needs. In addition, many States publish their own water-use reports in cooperation with the USGS.

Information on water use in the United States is now available on the Internet through the U.S. Geological Survey Water Resources Information home page. The Universal Resource Locator (URL) for the National Water-Use Home Page is: http://h2o.usgs.gov/public/watuse/.

It may be accessed by using a number of Web browser software packages.

\section{Instream-Flow Requirements}

Instream use is defined as any water use that occurs within the stream channel for such purposes as hydroelectric power generation, navigation, fish and wildlife preservation, water-quality improvement, and recreation. The National Water-Use Program compiles information for hydroelectric power. Quantitative estimates for most other instream uses are difficult to quantify and compile on a national scale. However, because such uses compete with traditional uses such as domestic, industrial, and irrigation, effective waterresources management requires that methods and procedures be devised to enable instream uses to be assessed quantitatively.

Regulatory instream-flow requirements are increasing at an unprecedented rate. Current activities in many States calls for substantial increases in instream flows to meet a variety of human and environmental needs. For example:

- Recent legislation in Florida requires substantial increases in instreamflow deliveries to Everglades National Park

- Releases from Jordanelle Reservoir to support fish habitat in Utah are six times greater than called for in the original 1960's design

- Efforts are underway in Nevada to convert irrigation water rights to instream-flow rights for Stillwater wetlands

- The economic market associated with whitewater rafting in Virginia has led the U.S. Army Corps of Engineers to investigate alternative release schedules

- Numerous projects in California call for increased instream flows for fish and wildlife preservation

\section{Water Use in the United States}

Approximately 339,000 million gallons per day of freshwater (about one-

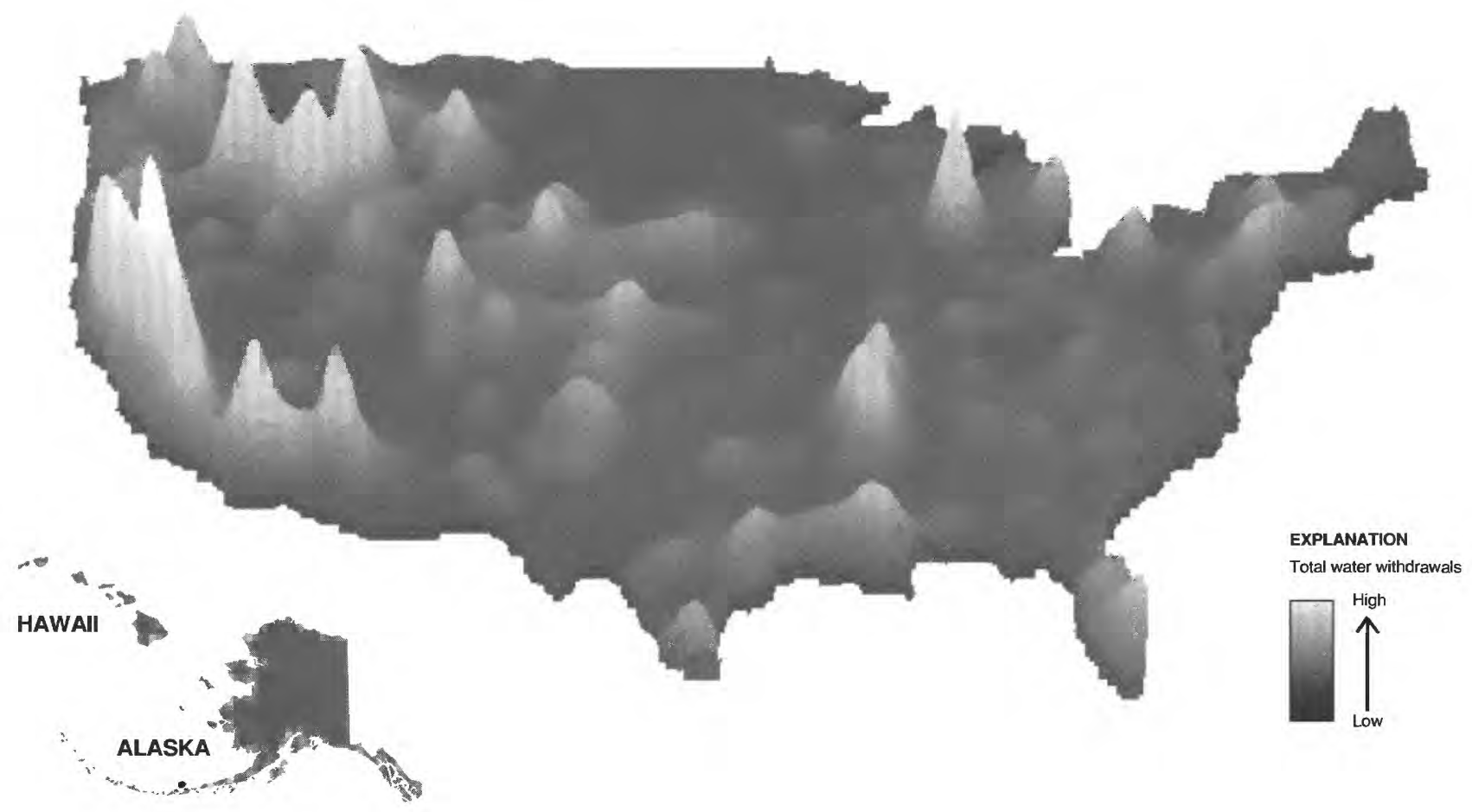

Figure 2. Total surface- and ground-water withdrawals, excluding water used for power generation. 
quarter of the national renewable supply) was withdrawn from streams, reservoirs, and wells during 1990 for use in the Nation's homes, cities, farms, and industries. After use, about 220,000 million gallons per day was returned to the natural system. Figure 2 illustrates water use, excluding water used for power generation. The following sections describe some prominent water issues and how the water is used in selected high-intensity use areas.

\section{Idaho}

Idaho ranks second in the irrigation of crops, which dwarfs all other water uses in the State. Idaho is a leading national producer of several crops including potatoes, barley, sugarbeets, hops, mint, onions, sweet corn, dried beans, alfalfa hay, and wheat. Agriculture predominates in the south-central and southeastern parts of the State along the Snake River and in tributary valleys adjacent to the Snake River Plain. Irrigation steadily increased by 37 percent from 1970 to 1985 and decreased 9 percent from 1985 to 1990 . Idaho uses more water for fish farms than any other State. The fish farms are conveniently located in spring outlets along the Snake River.

\section{California}

The Central Valley has long been one of the premier agricultural areas of California, as well as the Nation. It produces crops of the widest diversity and highest value of any comparable region in the world. Withdrawals for irrigation in California account for more than 20 percent of all irrigation in the United States, with most of the irrigation occurring in the Central Valley. Major irrigated crops include alfalfa, cotton, pasture, grapes, and wheat, as well as a wide assortment of nuts, fruit, and vegetables. The intensive agricultural development in the Central Valley is supported by groundwater pumpage and large imports of surface water. During the 1960's and the 1970's, withdrawals from wells caused water levels to decline hundreds of feet in the southern and western parts of the San Joaquin Valley. Overall, the net loss of aquifer storage resulted from inelastic compaction of clay beds that produced the largest volume of land subsidence in the world. However, in recent years, importing surface water, changing crop patterns, and decreasing ground-water withdrawals have controlled land subsidence in the seriously affected areas.

The Imperial Irrigation District, which is located southeast of the Central Valley, also is a productive agricultural area and receives water from the Colorado River. The total irrigated acreage in California has remained constant since 1975 , and water withdrawals declined from 1975 to 1990 because of active conservation programs, irrigation drainage problems, and changes in crop types.

\section{The High Plains}

The High Plains aquifer provides ground water to irrigate millions of acres and to support large livestock populations in the High Plains, which stretches south from the Dakotas to Texas and is bordered by the Rocky Mountains and the Mississippi River. Major crops include wheat, corn, sorghum, and cotton. Irrigation has declined in recent years because of substantial decreases in ground-water levels. Depletion of the High Plains aquifer system threatens the livelihood of millions of Americans and the existence of many small mid-America farm communities.

Changes in irrigation practices, such as from flood irrigation to more efficient sprinkler irrigation, and the education of farmers on water-saving techniques may slow the rate of ground-water depletion. Accurate estimates of pumpage throughout the High Plains will assist in determining the effectiveness of conservation programs and in assessing the viability of this major aquifer system.

\section{Arizona}

The Central Arizona Project (CAP), which was created to mitigate ground-water overdraft in central Arizona, conveys water up to 337 miles away from its source- - the Colorado River. The CAP deliveries are used primarily for irrigation and are the source for about 10 percent of the State's total water withdrawals. The principal crops in Arizona are cotton, hay, and grains.

Because detailed water-use information is required to monitor the effectiveness of conservation requirements and management plans, the Arizona Legislature passed the Ground-Water Management Act in 1980. This Act established the Arizona Department of Water resources, which administers the water law and manages the ground-water resources in designated Active Management Areas and Irrigation Non-Expansion Areas.

\section{The Northeast}

Excluding thermoelectric power withdrawals, public supply and domestic and commercial withdrawals dominate water use in the major urban centers in the Northeast, led by New York City and Philadelphia. Many of the major public supply utilities have implemented active water-conservation programs to increase dramatically the reliability of their water systems. Industries have implemented new water-conserving processes and increased recycling to decrease their wastewater discharges.

\section{IIIinois/Indiana}

Public supply withdrawals in Illinois rank fourth in the Nation, and Indiana ranks first in industrial withdrawals. Water for public supplies in the Chicago and the East St. Louis areas is withdrawn primarily from surface water to serve nearly one-half of the population in Illinois. Industries in the area are predominantly oil and ore refineries, and chemical and steel plants. Surface-water quality is a major concern because it is being degraded by sewage and industrial wastewater discharges in densely urbanized areas. Because of advances in water-treatment technology, the use of surface water has not yet been restricted.

\section{Florida}

Within an area that crosses the State from Tampa to Daytona Beach, large withdrawals satisfy demands for public supply, industrial, and irrigation water. The nine counties in the area are home to nearly 4 million people and to millions of vacationers that visit the area annually. Also, demands for water to support the Everglades National Park are at their highest.

Irrigation of sugarcane and citrus dominates water use in the six counties that comprise the Everglades Agricultural Area and the Indian River Citrus Area in Florida. About 1 million acres are irri- 